\title{
Precision of the dimensions of orthodontic bracket slots - systematic review
}

\section{Dokładność wymiarów szczelin zamków ortodontycznych - przegląd systematyczny}

\author{
Seweryn Kłos ${ }^{1}$, Joanna Janiszewska-Olszowska ${ }^{2}$ \\ 1 Prywatna praktyka stomatologiczna „Dentysta Rodzinny” w Człuchowie \\ Private dental practice „Dentysta Rodzinny” in Człuchów \\ ${ }^{2}$ Pomorski Uniwersytet Medyczny w Szczecinie, Zakład Stomatologii Zintegrowanej \\ Al. Powstańców Wlkp. 72, 70-111 Szczecin \\ Pomeranian Medical University in Szczecin, Department of Interdisciplinary Dentistry \\ $\triangle$ jjo@pum.edu.pl
}

\begin{abstract}
Introduction: The aim of this study was to revising and presenting results of in vitro studies referring to the precision of the dimensions of orthodontic brackets' slots.

Materials and methods: Search was proceeded for studies describing results of measurements of the dimensions of orthodontic brackets slots performed with the use of various available measuring instruments. Brackets from various manufacturers were taken into consideration. Search was performed in PubMed and Google Scholar. The following keywords were used: „bracket slot”, ,orthodontic bracket slot dimension”. Studies were included, if they based on two separate measurements: at the slot opening and along the slot bottom. Studies were rejected if they described an analysis of bracket slot structure or roughness without providing slot dimensions.
\end{abstract}

Results: Finally, 13 papers were selected from PubMed and 9 papers - from Google Scholar (all the papers from PubMed were found in Google Scholar as well). All the studies analysed, regardless of the method of measurement and material used for the manufacturing of orthodontic brackets revealed, that slot dimensions were higher or lower than the declared standard size. Moreover, analysis of slot appearance provided interesting information pertaining to the shape of bracket slots, e.g. parallelism, convergence or divergence of their walls.

Conclusions: Basing on the review it can be stated that orthodontic brackets are characterized by imperfections that may characterize single brackets, bracket sets or series. They may potentially influence the process of three-dimensional aligning of individual teeth during orthodontic treatment.

Keywords: orthodontic bracket; bracket slot; bracket slot dimension.

\section{ABSTRAKT}

Wstęp: Celem pracy było zebranie i przedstawienie wyników badań in vitro dotyczących dokładności wymiarów szczelin zamków ortodontycznych.

Materiały i metody: Poszukiwano prac opisujących wyniki przeprowadzonych za pomocą różnych narządzi pomiarów wielkości szczelin zamków ortodontycznych. Uwzględniano zamki różnych producentów. Wyszukiwania przeprowadzono w bazach PubMed i Google Scholar. Wykorzystano słowa kluczowe bracket slot (szczelina zamka) i orthodontic bracket slot dimension (wymiar szczeliny zamka ortodontycznego). Do przeglądu włączono tylko te badania, które opierały się na dwóch różnych pomiarach: u wylotu szczeliny zamka i wzdłuż podstawy szczeliny zamka. Odrzucano wszystkie artykuły, które opisywały badania nad strukturą i chropowatością powierzchni wewnętrznej szczeliny zamka bez podawania wymiarów szczelin.

Wyniki: Ostatecznie wybrano 13 artykułów spośród wyszukanych w bazie PubMed i dodatkowo 9 artykułów wyszukanych

przez Google Scholar (wszystkie artykuły z PubMed powtórzyły się w Google Scholar). Wszystkie badania, bez względu na sposób pomiaru oraz materiał, z jakiego zostały wykonane zamki ortodontyczne, wykazały, że wymiary slotu były większe lub mniejsze od deklarowanej standardowej wielkości. Ponadto badania obrazów slotów dostarczyły interesujących danych na temat ogólnego kształtu szczelin zamków, tj. równoległości ścian, ich zbieżności lub rozbieżności.

Wnioski: Na podstawie przedstawionego przeglądu piśmiennictwa można stwierdzić, że zamki ortodontyczne cechują niedoskonałości produkcyjne, które mogą występować w pojedynczym zamku, określonym zestawie bądź w całej serii zamków ortodontycznych. Może to mieć wpływ na precyzję trójwymiarowego ustawiania poszczególnych zębów podczas leczenia ortodontycznego.

Słowa kluczowe: zamek ortodontyczny; szczelina zamka; wymiar szczeliny zamka.

\section{INTRODUCTION}

WSTĘP

Orthodontic brackets are used in order to transfer orthodontic forces to the teeth. A bracket consists of the body and base with retention surface for the adhesive material and two (single

Zamki ortodontyczne są używane do przenoszenia sił ortodontycznych na zęby. Zamek składa się z trzonu połączonego z podstawą mającą powierzchnię retencyjną dla materiału wiążącego 
brackets) or, more frequently, four wings (twin brackets). A person undergoing orthodontic treatment usually has brackets bonded to most of the teeth [1]. Every bracket has a slot for the insertion of an archwire, which transfers corrective forces from the archwire to the tooth. Brackets are made of materials characterized by an adequate strength to transfer forces to the teeth, usually metal or ceramics.

Inserting an archwire, obturating a precise slot manufactured at an adequate angle allows generate forces moving the teeth according to three dimensions of space. These forces result from inserting the archwire into the bracket slot, thus discordance between these elements causes inadequate transferring of the designed inclination of the tooth on its periodontal ligament. Kusy and Whitley [2], creating an algorithm basing on wire and bracket dimensions, proved that their relative discordance is a decisive factor determining final position of the teeth on orthodontic treatment completion, especially through the sliding mechanics (moving archwire in the bracket slot). It should be noticed that dental alignment along the archwire and according to the angles referring to the values pre-programmed in bracket slots require possibly most precise fit of the archwire into the bracket. On the other side, in orthodontic treatment teeth are often moved along the archwire (sliding mechanics). This becomes easier, if friction is reduced due to a loose contact between archwire and bracket, but at the cost of a reduced precision of positioning the teeth.

Two slot sizes are available on the market: 0.018 " and 0.022 ". Achieving precise dimensions may be difficult, thus real slot dimensions may differ from those declared by the manufacturers. Metal orthodontic brackets are manufactured in casting techniques, milling or MIM method (Metal Injection Moulding) $[3,4,5]$. In the casting technique, previously prepared moulds are poured with a liquid metal alloy. Milling is machining a metal rail. The MIM method was invented in the USA in the 80. of the XX century and used to produce small elements [4]. Bracket production by MIM method proceeds with the use of an injection machine, which under pressure injects metal powders mixed with organic filler into a prepared mould; then in the process of baking the polymer is burned off and the metal particles merge.

The aim of the present study was to systematize the results of in vitro studies concerning the precision of orthodontic slot dimensions.

\section{MATERIALS AND METHODS}

The literature review was made in PubMed and Google Scholar. The process of selection of the studies has been presented on Figures 1 and 2. The following keywords were used for search: „bracket slot”, „orthodontic bracket slot dimension”.

Studies were included if they reported slot dimensions measured with the use of any instruments. The measurement had to be proceeded at the slot opening and at its bottom as described by Cash et al. [6] (Fig. 3). Brackets from different oraz 2 zamki pojedyncze (single brackets) lub, częściej, 4 skrzydełka (zamki podwójne - twin brackets). Osoba poddawana leczeniu ortodontycznemu na ogół ma zamki nałożone na większość zębów [1]. Każdy zamek ma szczelinę do osadzenia drucianego łuku leczniczego, która przenosi siły korekcyjne z łuku do zęba. Zamki ortodontyczne są wykonane z materiałów zapewniających wystarczającą wytrzymałość do przenoszenia tych sił na zęby, najczęściej z metalu lub ceramiki.

Wprowadzenie łuku wypełniającego precyzyjnie wykonaną pod odpowiednim kątem szczelinę zamka pozwala na wytwarzanie sił przesuwających zęby we wszystkich trzech kierunkach przestrzeni (trójwymiarowo). Siły te powstają w wyniku wprowadzenia drutu do szczeliny zamka, a nieprecyzyjne dopasowanie tych elementów powoduje niepełne przeniesienie zaprojektowanych wartości kąta nachylenia zęba na jego aparat zawieszeniowy. Kusy i Whitley [2], tworząc algorytm na podstawie wymiaru łuków i zamków, wykazali, że niedopasowanie obu tych elementów jest czynnikiem mającym wpływ na ostateczną pozycję zębów po zakończonym leczeniu, a w szczególności na mechanikę ślizgową (przemieszczanie łuku w szczelinie zamka). Należy bowiem zauważyć, że ustawianie zębów zgodnie z przebiegiem łuku i pod kątami odpowiadającymi wartościom zaprogramowanym w szczelinach zamków wymaga jak najbardziej precyzyjnego wzajemnego dopasowania wymiarów łuków i szczelin zamków. Jednakże w leczeniu ortodontycznym często przesuwa się zęby wzdłuż łuku leczniczego (mechanika ślizgowa). Jest to łatwiejsze przy mniejszym tarciu, gdy istnieje pewien luz między łukiem a zamkiem, jednak odbywa się kosztem zmniejszenia precyzji ustawiania zębów.

Na rynku dostępne są zamki o dwóch różnych wysokościach szczeliny: 0,018 i 0,022 cala. Uzyskanie dokładnie takich wartości może być trudne, zatem wymiary rzeczywiste mogą różnić się od deklarowanych przez producentów. Metalowe zamki ortodontyczne są produkowane za pomocą technik odlewania, frezowania lub metodą metal injection moulding (MIM) $[3,4,5]$. W technice odlewniczej stosuje się uprzednio przygotowane formy, które zostają zalane ciekłym stopem metalu.

Frezowanie polega na obróbce skrawaniem metalowej szyny. Metoda MIM została opracowana w Stanach Zjednoczonych na początku lat 80 . XX w. i znalazła zastosowanie w produkcji małych elementów [4]. Produkcja zamków metodą MIM odbywa się z użyciem maszyny do formowania wtryskowego, która pod ciśnieniem wprowadza proszki metali wymieszane ze spoiwem organicznym do przygotowanej formy; następnie w procesie wypiekania polimer ulega spaleniu, a metal łączy się w całość.

Celem niniejszej pracy było usystematyzowanie wyników badań in vitro na temat dokładności wymiarów szczelin zamków ortodontycznych.

\section{MATERIAtY I METODY}

Przegląd piśmiennictwa przeprowadzono za pomocą baz PubMed i Google Scholar. Proces selekcji prac (flow diagram) przedstawiono na rycinach 1 i 2. Wyszukiwanie prowadzono z wykorzystaniem słów kluczowych bracket slot (szczelina 


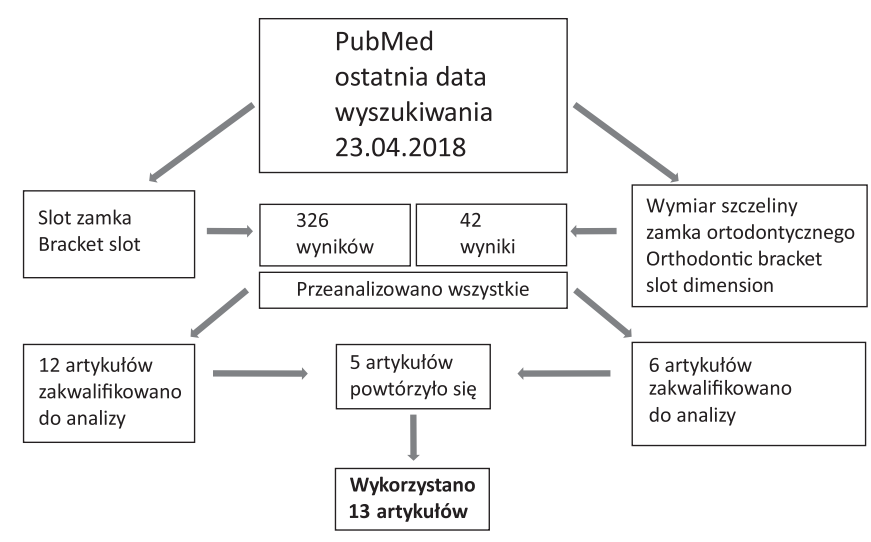

RYCINA 1. Schemat wyszukiwania w bazie PubMed

FIGURE 1. Flow diagram for the search in PubMed

manufacturers were taken into consideration. Studies were rejected if they only described bracket structure or roughness without providing slot dimensions.

\section{RESULTS}

Finally, 13 papers were selected from PubMed (Fig. 1), moreover 9 papers were selected from Google Scholar (Fig. 2); all papers from PubMed were repeated in Google Scholar. Thus the results of measurements of bracket slots have been provided in few publications $[2,6,7,8,9,10,11,12,13,14,15,16,17]$. The study material, methods and results of measurements by authors of each study have been provided in Table 1.

The authors of the papers included in the review have used various methods of measurement. The equipment used comprised: one-axis light microscope [6], scanning electron microscope [7, 8], stereomicroscope [9], electron microscope [9],

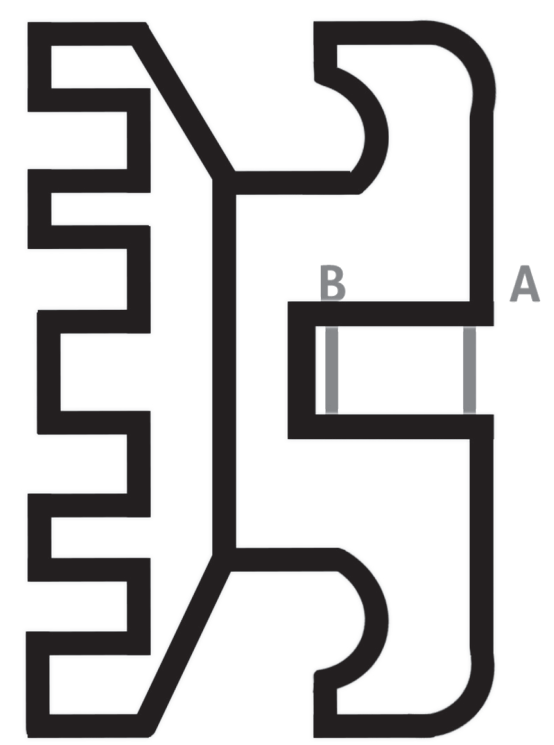

RYCINA 3. Miejsca pomiaru szczelin zamków: A - wylot szczeliny zamka, B - podstawa szczeliny zamka

FIGURE 3. The sites of bracket slots measurements: A - bracket slot opening, B - bracket slot base

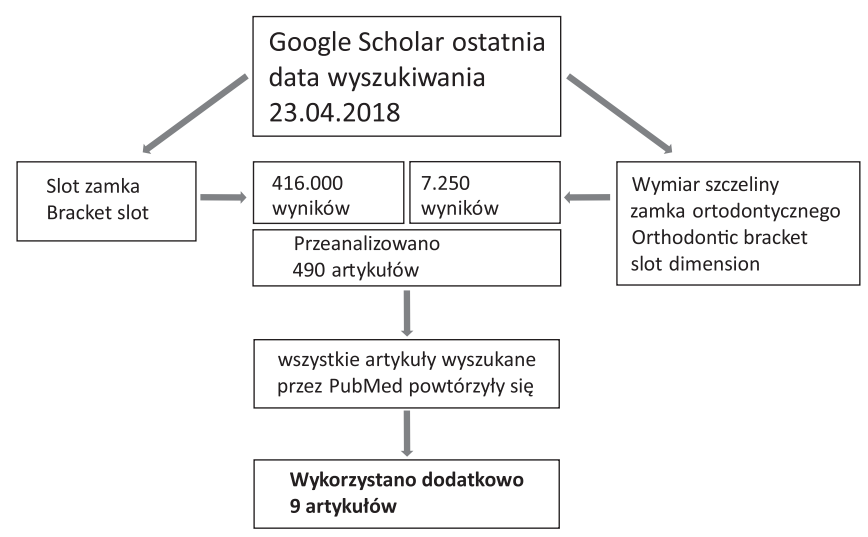

RYCINA 2. Schemat wyszukiwania w bazie Google Scholar

FIGURE 2. Flow diagram for the search in Google Scholar

zamka) i orthodontic bracket slot dimension (wymiar szczeliny zamka ortodontycznego).

Do przeglądu włączano badania, których autorzy przeprowadzali pomiary wielkości slotów za pomocą dowolnych narzędzi. Przeglądem objęto tylko te badania, które opierały się na dwóch różnych pomiarach: u wylotu szczeliny zamka i wzdłuż jej podstawy, jak opisali Cash i wsp. [6] (ryc. 3). Uwzględniono badania zamków różnych producentów. Odrzucano wszystkie artykuły, które opisywały jedynie badania struktury i chropowatości powierzchni wewnętrznej slotu bez pomiarów wielkości.

\section{WYNIKI}

Ostatecznie do przeglądu wyselekcjonowano z bazy PubMed 13 artykułów (ryc. 1) i dodatkowo z bazy Google Scholar 9 artykułów (ryc. 2). Wszystkie artykuły z PubMed powtórzyły się w Google Scholar. Wyniki pomiarów szczelin zamków ortodontycznych zostały zatem podane w nielicznych publikacjach $[2,6,7,8,9,10,11,12,13,14,15,16,17]$. Materiał badawczy, metodykę pomiaru oraz wyniki uzyskane przez autorów poszczególnych prac przedstawiono w tabeli 1.

Poszczególni badacze wykorzystali do pomiarów różne metody pomiarowe, jak: jednoosiowy mikroskop świetlny [6], skaningowy mikroskop elektronowy [7, 8], mikroskop stereoskopowy [9], mikroskop elektronowy [9], tester mikrotwardości [10], różne projektory profilowe [11,12], mikroskop świetlny z cyfrową lustrzanką jednoobiektywową [13], automatyczny bezkontaktowy system pomiaru wideo [14], zakres skrętu łuku stalowego o znanych wymiarach i skosie krawędzi [9, 15, 16], szczelinomierz mikrometryczny [16], a także kalibrowane wskaźniki szpilkowe (piny) [17]. Autorzy części analizowanych prac przedstawili uzyskane wyniki w postaci odchyleń w stosunku do wymiarów deklarowanych przez producentów jako wartości bezwzględne (w milimetrach bądź calach) lub też jako odchylenia względne (w procentach). Inni podali zakres skrętu łuku stalowego („gry szczelinowej”) w stopniach. Trudne jest zatem porównywanie wyników badań opublikowanych w poszczególnych pracach. 


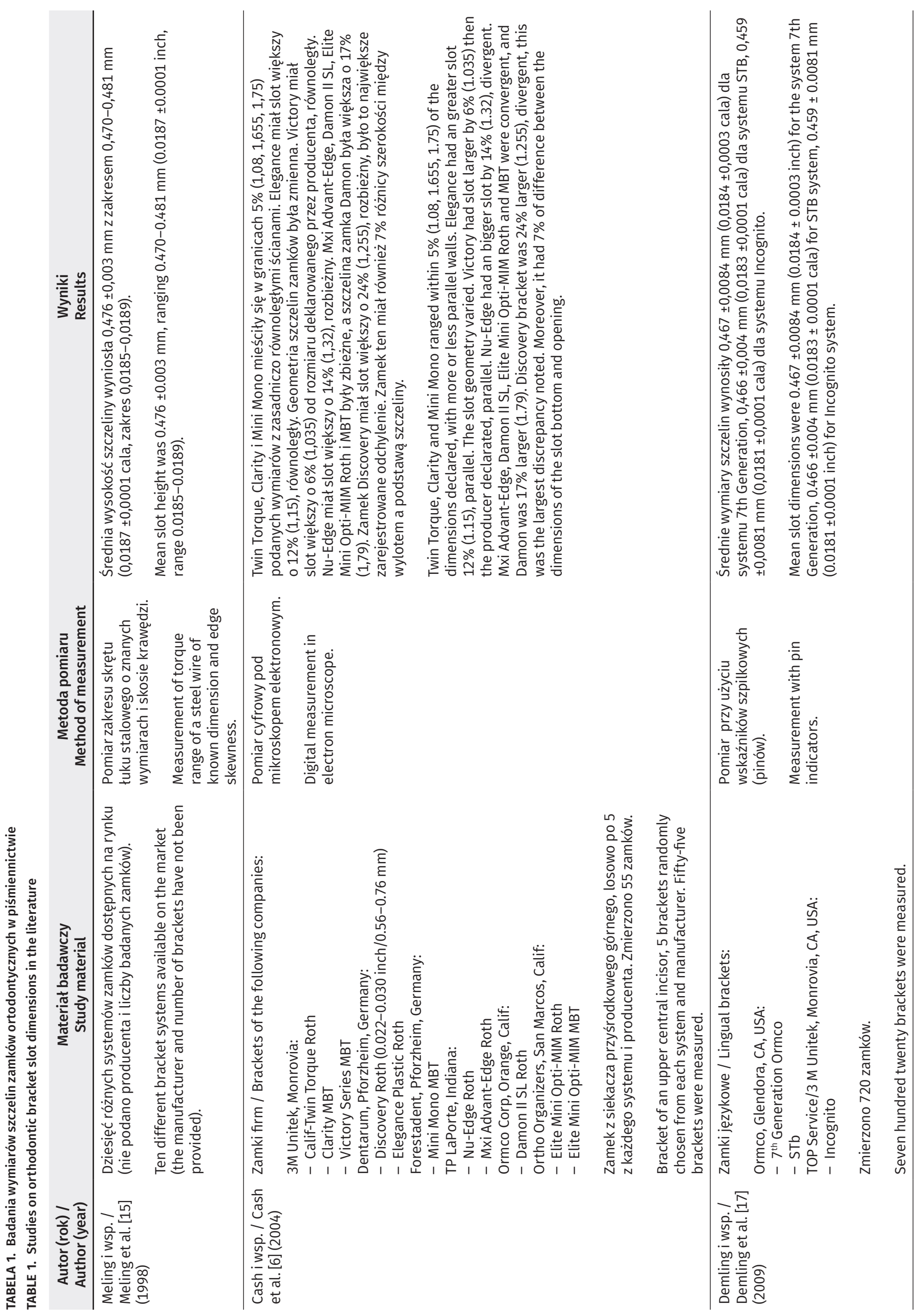




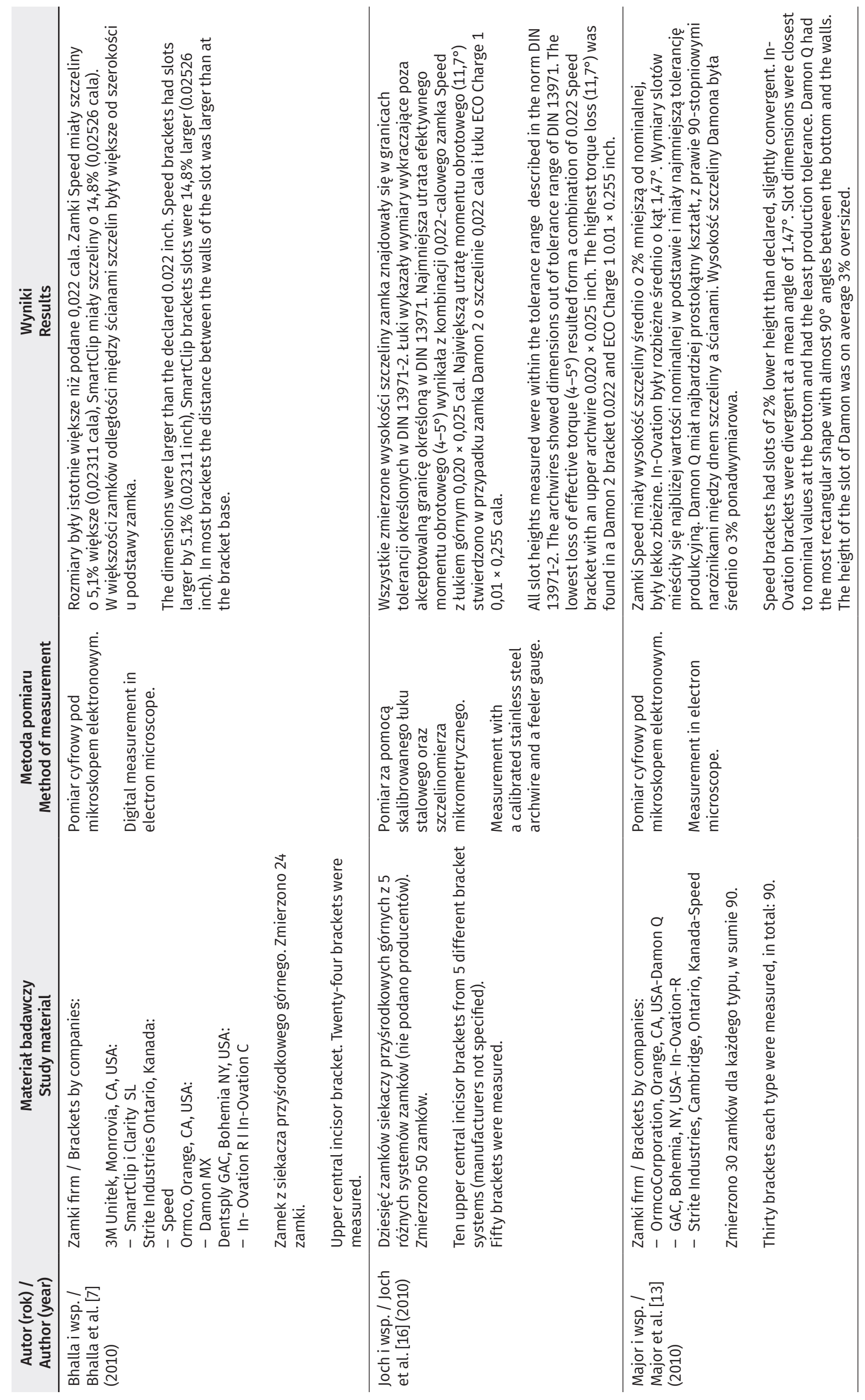




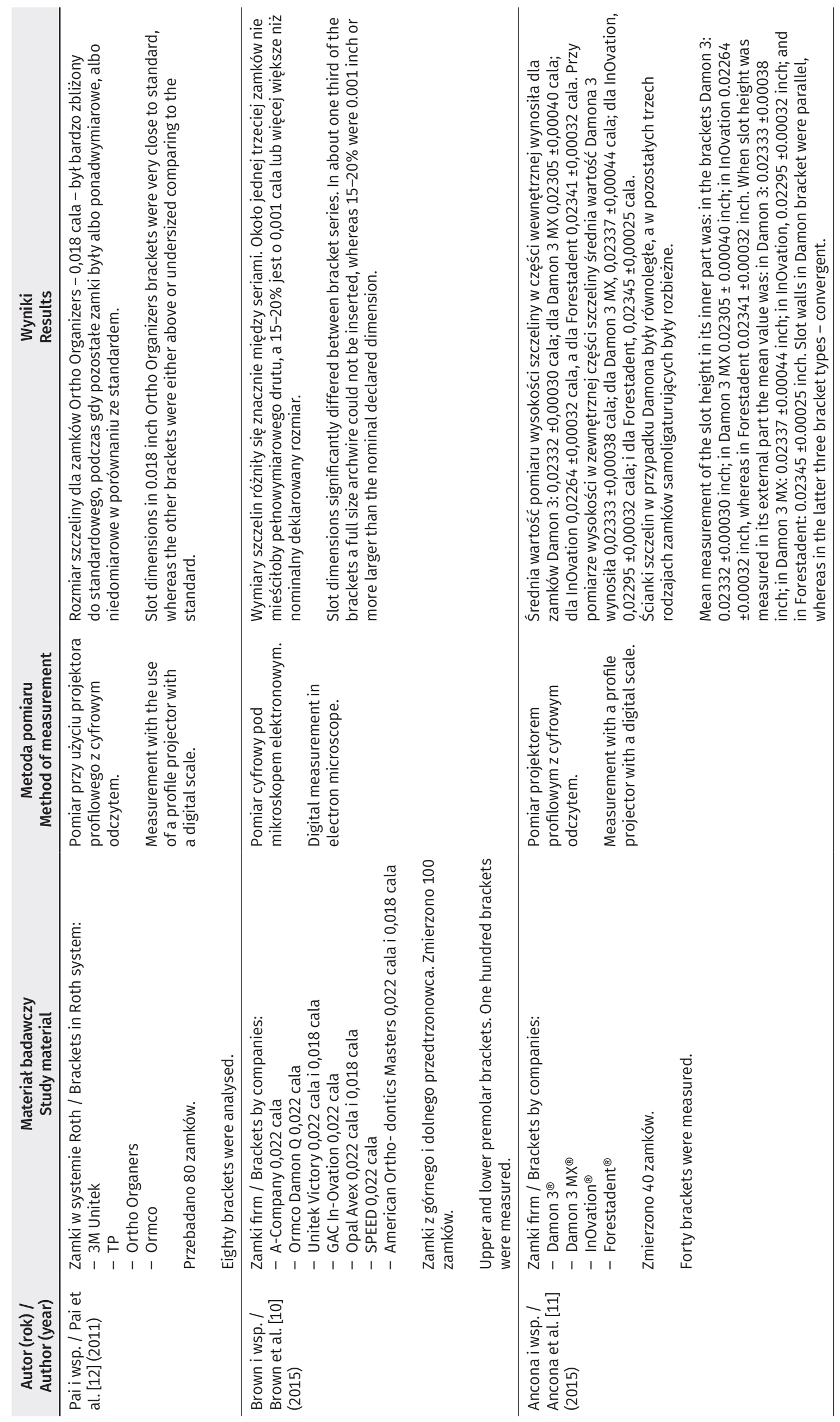




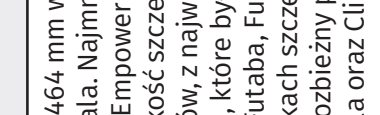

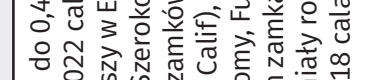

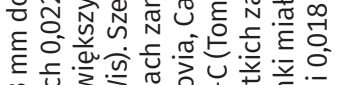

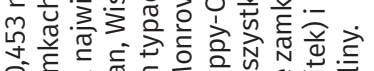

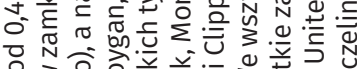

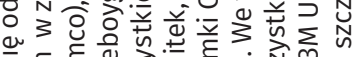

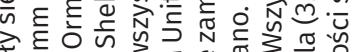

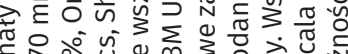

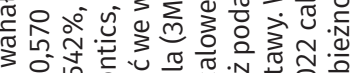
等응 要

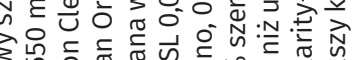

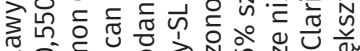

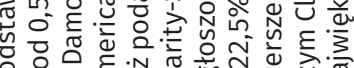

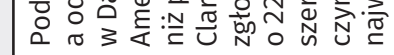

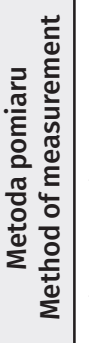

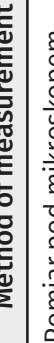

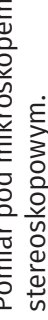

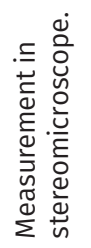

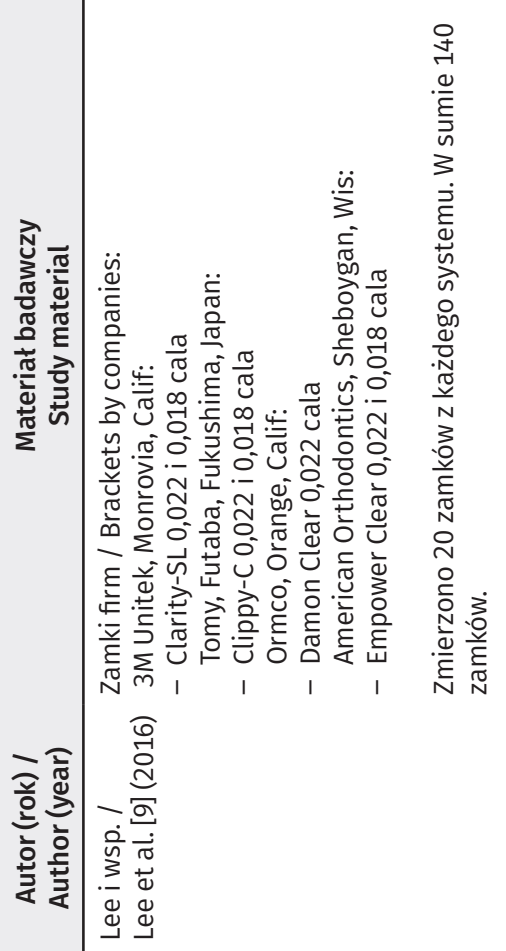

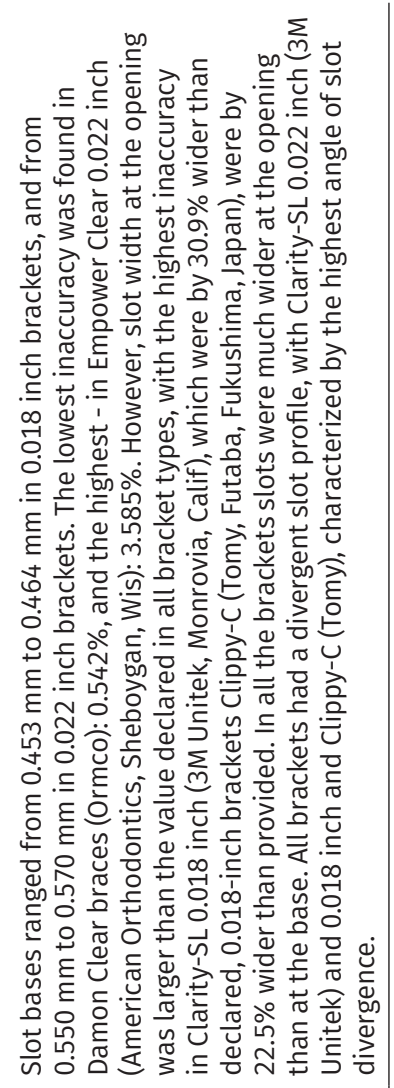

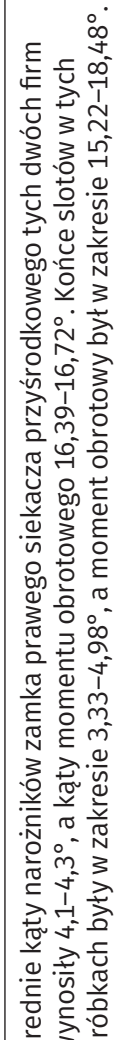

$\therefore \circ$

空

ठํํำ

은

운

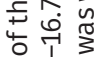

जु

过

는

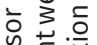

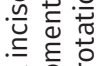

줄

⿶.

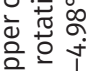

空

ज范

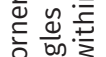

용

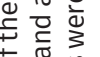

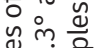

क力

ชิ

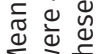

的文 $\sum 3$

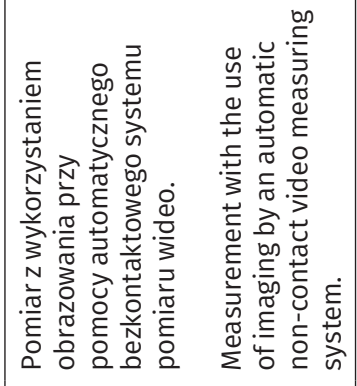

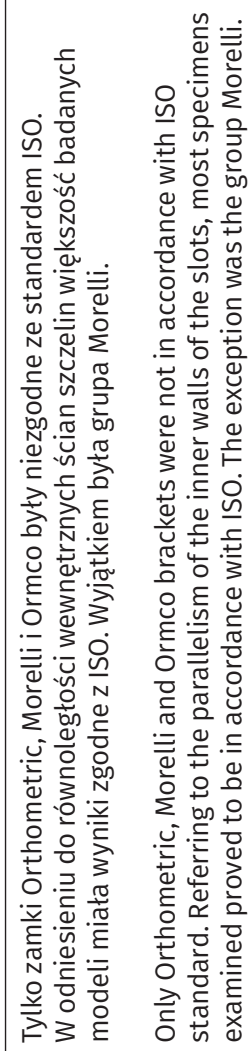

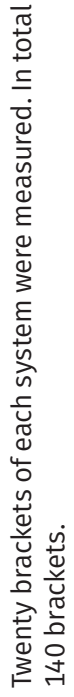

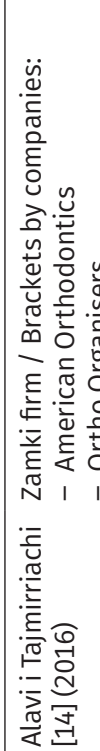

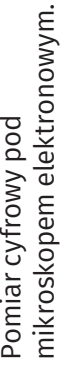

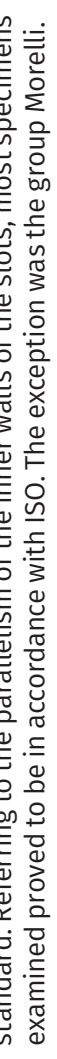

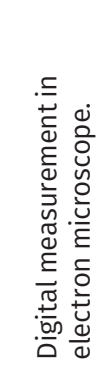

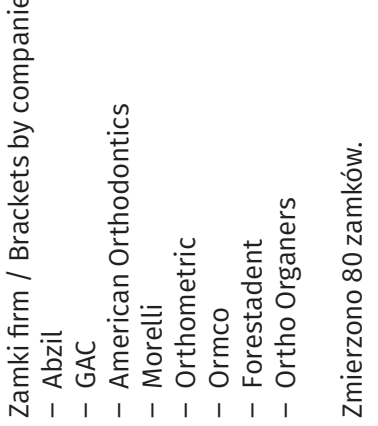


tester of microhardness [10], various profile projectors [11, 12], a light microscope with a single-lens reflex camera [13], automatic non-contact system for video measurement [14], range of torque of a steel wire of a given dimension and edge skewness $[9,15,16]$, micrometric feeler gauge $[16]$ as well as calibrated pin indicators [17]. The authors of the studies analysed have presented their results as deviations from the dimension declared by the manufacturers in absolute values in millimeters or inches or as relative deviations (in percentages). Some authors provided the range of rotation of a rectangular steel wire („slot play”) in degrees. It is thus difficult to compare them results of different studies.

The study material comprised various brackets, including: conventional metal brackets $[6,12,14]$, esthetic brackets [6], self-ligating brackets $[6,8,10,11,13]$, self-ligating ceramic brackets [9], lingual brackets [17] in the number from 5 brackets randomly chosen from 11 different systems [6] to 720 lingual brackets by various manufacturers [17]. In two studies the manufacturer has not been specified $[15,16]$. It is thus impossible to compare between brackets of different slot sizes, made from various material, manufactured with different methods or even between brackets manufactured years ago and recently.

Interesting observations have been reported concerning the shape of bracket slots. Ancona et al. [11] have described bracket slots as parallel, if slot height was the same as the opening as at the bottom; diverge, if slot height was higher at the opening than at the bottom and converge, if slot height was lower at the opening than at the bottom. The results of the studies analysed indicate that the contralateral walls are not always parallel. Some brackets had convergent and others - divergent walls; moreover a variability of slot width at the opening and at the bottom was found. Another problem pertained to the precision of internal angles of the bracket slot and the orientation of its walls referring to the bottom. When the inner angles of the slot are rounded, a precise angular contact between the wire and the slot becomes impossible $[17,18]$. It causes a premature loss of the torquing moment similarly as in case of bracket deformation resulting from imperfect material used for manufacture or imperfect manufacturing process. A loss of rotational moment may also occur when rectangular wires of low dimensions are used.

\section{DISCUSSION}

Various bracket systems have been invented in order to reduce or eliminate the need to introduce the first, second and third order bends, resulting in a simple treatment technique. Various manufacturers have used these recommendations for the production of orthodontic brackets with angulation, torque and in-out values built-in. Straight wire technique could possibly be improved by using final values of torque, angulation and rotational moment in the slots. It seems rational as well to establish international norms based on average tooth size for proper ranges of these values [19].
Materiał badawczy stanowiły różne zamki: konwencjonalne metalowe $[6,12,14]$, estetyczne [6], samoligaturujące [6, $8,10,11,13]$, samoligaturujące ceramiczne [9], językowe [17] w liczbie od 5 sztuk wybranych losowo spośród 11 różnych systemów [6] do 720 zamków językowych różnych producentów [17]. W 2 pracach nie podano producenta zamków [15, 16]. Nie pozwala to na porównywanie zamków o różnych wysokościach szczelin, wykonanych z różnych materiałów, produkowanych różnymi metodami czy też zamków produkowanych dawniej i obecnie.

Ciekawe obserwacje dotyczyły kształtu szczelin. Ancona i wsp. [11] opisali szczeliny zamków jako: równoległe, gdy wysokość szczeliny była taka sama u wylotu i przy dnie; rozbieżne, gdy wysokość szczeliny była większa u wylotu i mniejsza w kierunku jej najgłębszej części; zbieżne, gdy wysokość szczeliny była mniejsza u wylotu i większa w najgłębszej części szczeliny. Wyniki analizowanych badań wskazują, że przebieg przeciwstawnych ścian szczeliny zamka nie zawsze jest równoległy. Ściany niektórych zamków były zbieżne, a innych rozbieżne; poza tym wykazano zmienność szerokości na górze szczeliny i u podstawy. Dodatkowy problem dotyczył zachowania wewnętrznych kątów szczeliny zamka i orientacji ścian względem podstawy. Gdy wewnętrzne kąty szczeliny zamka są zaokrąglone, niemożliwy staje się precyzyjny kątowy kontakt między drutem a szczeliną $[17,18]$. Powoduje to przedwczesną utratę momentu obrotowego, podobnie jak wówczas, gdy dojdzie do deformacji zamka z powodu niedoskonałości materiału, z którego został wykonany oraz samego procesu produkcyjnego. Może również wystąpić utrata momentu obrotowego przy użyciu drutów prostokątnych o niewielkich wymiarach.

\section{DYSKUSJA}

Poszczególne systemy zamków ortodontycznych zostały opracowane w celu zmniejszenia zapotrzebowania lub uniknięcia potrzeby wprowadzania na łukach leczniczych dogięć pierwszego, drugiego i trzeciego rzędu, a tym samym uzyskania prostej techniki leczniczej. Różne firmy wykorzystały te zalecenia do produkcji zamków ortodontycznych z wbudowanymi wartościami torku, angulacji czy in-out. Być może obecnie technikę łuku prostego można by ulepszyć, uwzględniając dokładne wartości końcowe torku, angulacji i momentu obrotowego w slotach. Sensowne wydaje się także określenie międzynarodowych norm opartych na średniej wielkości zębów dla korzystnych zakresów tych wartości [19].

Autorzy analizowanych prac stwierdzili, że szczeliny zamków swoimi wymiarami nie odpowiadają deklarowanym wartościom, są zwykle większe lub mniejsze niż deklarowane przez producentów. Według badań Bennetta [20] nawet przy użyciu podobnego drutu zamki różnych firm wykazywały różne funkcje odtwarzania momentu obrotowego, a we wszystkich ocenianych zamkach wymiary szczeliny były większe niż te deklarowane przez producentów. Dodatkowo Siatkowski [21] stwierdził, że producenci zamków w Europie używają 
The authors of the studies analysed in this review have found that slot brackets' dimensions are not in accordance with the values declared; they are usually larger or smaller than declared by the manufacturers. According to Bennett [20], even when similar wires were used, brackets by different manufacturers showed a various reflection of the rotational moment and the slots were larger than declared in all brackets assessed. Moreover, Siatkowski [21] stated that in Europe the manufacturers use metric equipment, whereas American calibration is based on the English system of measurements, preventing precise device calibration. For this reason, 0.022 slots in brackets made in Europe are often $4.22 \%$ larger.

These factors influence the precision of three-dimensional tooth aligning during orthodontic treatment. Orthodontists should be aware that systems of brackets and wires commonly used in straight-wire technique might not ensure three-dimensional control required in order to achieve a positive treatment effect. It can be especially visible in cases, where a correction of incisor inclination is desirable. The clinician should remember that in order to overcome the imprecise production dimensions an additional rotational moment might be needed. The necessity of introducing wire bends significantly reduces the simplicity and effectiveness if a "preadjusted bracket system". It can be even thought that it may encourage using edgewise appliances [6].

Since production imperfections were found both in single brackets and in whole production series, it is not very probable that a clinician has complete sets of perfect brackets, consequently acting as "preadjusted". It seems thus justified to "avoid thinking that all brackets are more or less the same" [22]. Most orthodontists prefer a particular bracket system; it is important to know the system used for the treatment and remember why it has been chosen [21]. Some brackets sold as "preadjusted” are not able to generate a rotational moment without additional wire bending. It should be thus expected, that a need may occur to transfer the forces by the use of wire bends in three dimensions of space in order to overcome the bracket's imperfection.

\section{CONCLUSIONS}

1. The bracket slots are characterized by production disadvantages, which may occur in single brackets, a particular set or in a whole bracket series.

2. The imperfections found in orthodontic bracket slots referred to their dimensions and shapes.

3. The slots' shape disadvantages described were: convergence or divergence of their walls and rounding of their inner angles.

4. It cannot be excluded that production imperfections may influence the precision of three-dimensional aligning of individual teeth during orthodontic treatment. oprzyrządowania metrycznego, a amerykańskie oparte jest na anglosaskim systemie miar, co uniemożliwia precyzyjne skalibrowanie urządzeń. Powoduje to, że szczeliny 0,022 cala w zamkach wykonanych w Europie są często większe o 4,22\%.

Ma to wpływ na precyzję trójwymiarowego ustawiania poszczególnych zębów podczas leczenia ortodontycznego. Lekarze ortodonci powinni zdawać sobie sprawę z tego, że systemy zamków i łuków powszechnie stosowanych w technice łuku prostego mogą nie zapewniać trójwymiarowej kontroli wymaganej w celu uzyskania korzystnego wyniku leczenia. Może to być szczególnie widoczne w przypadkach, w których wymagana jest korekta nachylenia siekacza. Lekarz powinien być świadomy, że w celu przezwyciężenia niedokładnych wymiarów produkcyjnych może być potrzebny dodatkowy moment obrotowy. Konieczność wprowadzania dogięć wyraźnie zmniejsza prostotę i skuteczność „wstępnie wyregulowanego" systemu zamków. Niektórzy uważają nawet, że może zachęcić lekarza do faworyzowania stosowania aparatów typu edgewise [6].

Z uwagi na fakt, że wady produkcyjne występowały zarówno pojedynczo, jak i w całych zestawach zamków danej serii produkcyjnej, jest mało prawdopodobne, aby lekarz posiadał kompletne zestawy idealnych zamków, które konsekwentnie działałyby jak „zaprogramowane”. Słuszny wydaje się zatem postulat, aby „unikać myślenia, że wszystkie zamki są mniej więcej takie same" [22]. Większość ortodontów preferuje konkretny system zamków; ważne jest, aby znać ten stosowany w leczeniu i pamiętać, dlaczego został wybrany [21]. Niektóre zamki sprzedawane jako „wstępnie wyregulowane” nie są w stanie wytworzyć momentu obrotowego zęba bez dodatkowego doginania drutu. Należy zatem spodziewać się, że może wystąpić potrzeba, aby przenosić siły poprzez stosowanie dogięć na łuku w trzech płaszczyznach przestrzeni w celu pokonania niedostatków budowy zamka.

\section{WNIOSKI}

1. Szczeliny zamków ortodontycznych cechują niedoskonałości produkcyjne, które mogą występować w pojedynczym zamku, określonym zestawie bądź w całej serii zamków ortodontycznych.

2. Stwierdzone defekty produkcyjne szczelin zamków ortodontycznych dotyczyły ich wymiarów oraz kształtu.

3. Opisane niedostatki kształtu szczelin zamków stanowiły: zbieżność lub rozbieżność ich ścian oraz zaokrąglenia wewnętrznych kątów.

4. Nie można wykluczyć, że niedoskonałości produkcyjne szczelin zamków mogą mieć wpływ na precyzję trójwymiarowego ustawiania poszczególnych zębów podczas leczenia ortodontycznego. 


\section{REFERENCES / PIŚMIENNICTWO}

1. Orthodontic bracket US 48387886 A James F. Reher, Farrokh Farzin-Nia 1987.

2. Kusy R, Whitley J. Assessment of second-order clearances between orthodontic archwires and bracket slots via the critical contact angle for binding. Angle Orthod 1999;69(1):71-80. doi: 10.1043/0003-3219 (1999)069<0071:AOSOCB>2.3.C0;2.

3. Alavi S, Kachuie M. Assessment of the hardness of different orthodontic wires and brackets produced by metal injection molding and conventional methods. Dent Res J (Isfahan) 2017;14(4):282-7.

4. Floria G, Franchi L. Metal injection molding in orthodontics. Virtual J Orthod 1997;2:1. http://vjo. it/five/mim.htm (20.01.2019).

5. Kinkard C. Focus: medical plant tour: metal injection molding smiles. Injection Molding Magazine. http://www.immnet.com/articleprintable. html?article=1962 (20.02.2019).

6. Cash AC, Good SA, Curtis RV, McDonald F. An evaluation of slot size in orthodontic brackets - are standards as expected? Angle Orthod 2004;74(4):450-3. doi: 10.1043/0003-3219(2004)074<0450:AEOSSI> 2.0.CO;2.

7. Bhalla NB, Good SA. McDonald F, Sherriff M, Cash AC. Assessment of slot sizes in self-ligating brackets using electron microscopy. Aust Orthodox J 2010;26(1):38-41

8. Erduran RH, Maeda FA, Ortiz SR, Triviño T, Fuziy A, Carvalho PE. Analysis on the precision of the dimensions of self-ligating brackets. Microsc Res Tech 2016;79(12):1188-92. doi: 10.1002/jemt.22774.

9. Lee Y, Lee DY, Kim YR. Dimensional accuracy of ceramic self-ligating brackets and estimates of theoretical torsional play. Angle Orthod 2016;86(5):804-9. doi: 10.2319/092415-647.1.

10. Brown P, Wagner W, Choi H. Orthodontic bracket slot dimensions as measured from entire bracket series. Angle Orthod 2015;85(4):678-82. doi: 10.2319/042814-307.1.
11. Ancona MAL, Díaz RR, Rodríguez FM, Olvera SP. Variations in slot size of self-ligating brackets. Revista Mexicana de Ortodoncia 2015;3(4):224-7. doi: 10.1016/j.rmo.2016.03.058.

12. Pai VS, Pai SS, Krishna S, Swetha M. Evaluation of slot size in orthodontic brackets: Are standards as expected? J Indian Orthod Soc 2011;45(4):169-74.

13. Major TW, Carey JP, Nobes DS, Major PW. Orthodontic bracket manufacturing tolerances and dimensional differences between select self-ligating brackets. J Dent Biomech 2010;2010:781321. doi: 10.4061/2010/781321.

14. Alavi S, Tajmirriahi F. Assessment of dimensional accuracy of preadjusted metal injection molding orthodontic brackets. Dent Res J (Isfahan) 2016;13(5):440-5.

15. Meling TR, Odegaard J, Segner D. On bracket slot height: a methodologic study. Am J Orthod Dentofacial Orthop 1998;113(4):387-93.

16. Joch A, Pichelmayer M, Weiland F. Bracket slot and archwire dimensions: manufacturing precision and third order clearance. J Orthod 2010;37(4):241-9. doi: 10.1179/14653121043182.

17. Demling A, Dittmer MP, Schwestka-Polly R. Comparative analysis of slot dimension in lingual bracket system. Head Face Med 2009;5:27. doi: 10.1186/1746-160X-5-27.

18. Kapur-Wadhwa R. Physical and mechanical properties affecting torque control. J Clin Orthod 2004;38(6):335-40.

19. Arreghini A, Lombardo L, Mollica F, Siciliani G. Torque expression capacity of 0.018 and 0.022 bracket slots by changing archwire material and cross section. Prog Orthod 2014;15:53. doi: 10.1186/s40510-014-0053-x.

20. Bennett J. Fundamentals of orthodontic bracket selection. London: LeGrande Publishing; 2010.

21. Siatkowski RE. Loss of anterior torque control due to variations in bracket slot and archwire dimensions. J Clin Orthod 1999;33(9):508-10.

22. English JD, Briss BS, Jamieson SA, Kastropet MC, Castelein PT, Deleon E, et al. Common errors in preparing for and completing the American Board of Orthodontics clinical examination. Am J Orthod Dentofacial Orthop 2011;139(1):136-7. doi: 10.1016/j.ajodo.2010.11.005. 